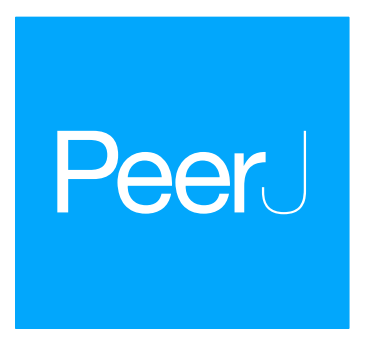

Submitted 1 March 2018

Accepted 2 June 2018

Published 19 June 2018

Corresponding author Damián Eduardo Perez, trophon@gmail.com

Academic editor Kenneth De Baets

Additional Information and Declarations can be found on page 12

DOI 10.7717/peerj.5051

Copyright

2018 Perez and Santelli

Distributed under

Creative Commons CC-BY 4.0

OPEN ACCESS

\section{Allometric shell growth in infaunal burrowing bivalves: examples of the archiheterodonts Claibornicardia paleopatagonica (Ihering, 1903) and Crassatella kokeni Ihering, 1899}

\author{
Damián Eduardo Perez ${ }^{*}$ and María Belén Santelli \\ División Paleoinvertebrados, Museo Argentino de Ciencias Naturales “Bernardino Rivadavia”, Buenos Aires, \\ Argentina \\ These authors contributed equally to this work.
}

\section{ABSTRACT}

We present two cases of study of ontogenetic allometry in outlines of bivalves using longitudinal data, a rarity among fossils, based on the preserved post-larval record of shells. The examples are two infaunal burrowing bivalves of the southern South America, Claibornicardia paleopatagonica (Archiheterodonta: Carditidae) (early Paleocene) and Crassatella kokeni (Archiheterodonta: Crassatellidae) (late Oligocenelate Miocene). Outline analyses were conducted using a geometric morphometric approach (Elliptic Fourier Analysis), obtaining successive outlines from shells' growth lines, which were used to reconstruct ontogenetic trajectories. In both taxa, ontogenetic changes are characterized by the presence of positive allometry in the extension of posterior end, resulting in elongated adult shells. This particular allometric growth is known in others infaunal burrowing bivalves (Claibornicardia alticostata and some Spissatella species) and the resulting adult morphology is present in representatives of several groups (e.g., Carditidae, Crassatellidae, Veneridae, Trigoniidae). Taxonomic, ecological and evolutionary implications of this allometric growth pattern are discussed.

Subjects Evolutionary Studies, Marine Biology, Paleontology, Zoology

Keywords Geometric morphometrics, Ontogeny, Crassatella, Claibornicardia, Allometric growth, Paleoecology, Archiheterodonta, Elliptic Fourier analysis

\section{INTRODUCTION}

According to the Gould-Mosimann school (defined by Klingenberg, 1998), 'allometry' is the association between size and shape. The concept of allometry implies variation of a trait associated with variation of the overall size of an organism (Klingenberg, 1998). Size of an organism can be determined by its own biological growth (or ontogeny), and in these cases, allometry is the covariation between shape and growth through its life-span. This allometry is known as "ontogenetic allometry" (Klingenberg, 1996a; Klingenberg, 1998). Studies on ontogenetic allometry mainly use "cross-sectional" data (each individual is measured at a single stage, and an average allometric trajectory is estimated from a composite sample from many individuals). Some ones use "longitudinal" data 
(e.g., Klingenberg, 1996b; Maunz \& German, 1997) (each individual is measured multiple times during their growths, and individual variability in allometric trajectories is obtained). Cases of "cross-sectional" data (sensu Klingenberg, 1996b) are frequent in paleontological studies, for example in trilobites (see Hughes, Minelli \& Fusco, 2006 and references herein), Cambrian arthropods (e.g., Haug et al., 2011), crinoids (e.g., Brower, 1988), gastropods (e.g., Gould, 1966a), diapsids (e.g., Ezcurra \& Butler, 2015), dinosaurs (e.g., Horner \& Goodwin, 2006; Horner \& Goodwin, 2009), or mammals (e.g., Christiansen, 2012). "Longitudinal" studies (sensu Klingenberg, 1996b) are not possible for many fossil organisms, but are viable in organisms with accretionary growth. Some examples are shelled molluscs (Urdy et al., 2010), brachiopods (Rudwick, 1968; Ackerly, 1989; Tomašových, Sandra \& Labarbera, 2008), or ammonoids (Korn, 2012; Korn, 2017; De Baets, Klug \& Monnet, 2013). Some researches often remain focused on adult stages, not taking into account the complete ontogeny, what is necessary for a more holistic view.

Bivalves show accretionary growth in their shells where the mantle adds constantly new layers of calcium carbonate to the edge (Pannella \& Maclintock, 1968). Therefore, they preserve in their shells a complete record of external traits of their post-larval life-spans (Crampton \& Maxwell, 2000), making them a source of "longitudinal" data (sensu Klingenberg, 1996b) for construction of ontogenetic trajectories. In a pioneer contribution, Crampton \& Maxwell (2000) elaborated a methodology to explore this particular growth in bivalves. They re-constructed the ontogenetic trajectories of $\mathrm{New}$ Zealand species of Spissatella (Bivalvia: Crassatellidae) and related their allometric growth to macroevolutionary trends in the clade.

From the paleoecological point of view, fossil bivalves are one of the most valuable tools, as different morphologies of bivalve shell are strongly related to modes of life and environmental characteristics (Stanley, 1970). Infaunal burrowing habit of life is the most extended among bivalves, consisting of the penetration of soft substrates by means of a pedal locomotion while maintaining a life position of, at least, partial burial (Stanley, 1970).

Geometric morphometrics is a very useful tool for study of allometry and ontogeny (Zelditch, Bookstein \& Lundrigan, 1992; Fink \& Zelditch, 1995; Mitteroecker et al., 2004; Mitteroecker, Gunz \& Bookstein, 2005; Monteiro et al., 2005; among others, see a revision on this topic in Adams, Rohlf \& Slice, 2013). Morphometric methods are objective, reliable and repeatable tools for quantify patterns of shape changes (Brown \& Vavrek, 2015). Geometric morphometric allows visually strong graphical representations of allometry studies (Adams, Rohlf \& Slice, 2013). In particular, outline shape analyses allow to study the variation in this key character, the outline, which reflects autoecological features in bivalves according to Stanley (1970) and Stanley (1975). The aim of this contribution is to study ontogenetic series in two examples of infaunal burrowing bivalves, Claibornicardia paleopatagonica (Ihering, 1903) (Archiheterodonta: Carditidae) and Crassatella kokeni (Ihering, 1899) (Archiheterodonta: Crassatellidae). Variability in shape of these two bivalves led previous authors to define new species based on possible juvenile specimens, Venericardia camachoi (Vigilante, 1977) and C. patagonicus (Ihering, 1907) (nowadays considered as synonymies of C. paleopatagonica and C. kokeni, respectively). Presence of allometric growth is tested and changes in shape in these species, and changes present in other infaunal bivalves, 
as well as their paleoecological implications, are discussed. Also, this contribution is an attempt to apply and to expand the methodology developed by Crampton \& Maxwell (2000). As is already mentioned by Crampton \& Maxwell (2000), Gould (1989, p. 537) noted that "Natural history is a science of relative frequencies"; and as these authors indicated "advance in many fields of palaeontological debate requires compilation of detailed observations across diverse fossil groups and time spans" (Crampton \& Maxwell, 2000, p. 400). The present is a contribution for thickening the literature of cases studying allometry patterns, and this is necessary since a debate addressing the relative frequencies of different phenomena only advance through the compilation of such cases.

\section{MATERIALS \& METHODS}

\section{Terminology and theoretical background}

All terms regarding allometry follow the definitions provided by Klingenberg (1998). Positive allometry refers to a trait that increases respect to another one (a positive deviation to expected isometry), and negative allometry is the opposite. Geometric Morphometrics and Elliptic Fourier Analysis (EFA) terminologies are explained in Kuhl \& Giardina (1982), Lestrel (1997), and Crampton (1995).

According to Crampton \& Maxwell (2000), two outlines with identical shapes and differing only in size will occupy the same point in a morphospace as the distance in this space is a measure of shape difference, a statement that was followed to perform the analysis in this paper.

Bivalve species studied herein are considered as infaunal free burrowing bivalves because they live under the water/sediment interphase and they are not-attached by their byssus. This categorization was described by Stanley (1970) and its followed in this contribution. From this point onwards, this mode of life will be called as "infaunal".

\section{Taxon sampling}

Allometric growth was studied in two species from the Cenozoic of Argentina, C. paleopatagonica (Ihering, 1903) (Archiheterodonta: Carditidae) (Fig. 1A) and C. kokeni (Ihering, 1899) (Archiheterodonta: Crassatellidae) (Fig. 1B). Archiheterodonts are nonsiphonate bivalves, being mainly restricted to shallow infaunal free burrowing. All fossil shells used in this study are housed at Museo Argentino de Ciencias Naturales "Bernardino Rivadavia" (MACN-Pi and CIRGEO-PI) and Paleontological Collection of Universidad de Buenos Aires (CPBA). Sampling details are summarized in Data S1.

The carditid species represents the most ancient record for its genus, being recorded in the early Danian of Patagonia (Argentina), in the Roca, Jagüel and Salamanca formations (Río Negro, Neuquén and Chubut provinces) and was recently included by Pérez \& Del Río (2017) in the genus Claibornicardia (Stenzel \& Krause, 1957). This taxon is also recognised in the late Paleocene-early Oligocene of North America and Europe. In these analyses 15 well-preserved shells of C. paleopatagonica from Puesto Ramírez (Salamanca Formation, Río Negro Province) (MACN-Pi 5197) were used. The specimen previously assigned to Venericardia camachoi by Vigilante (1977) is also included in MACN-Pi 5197. 


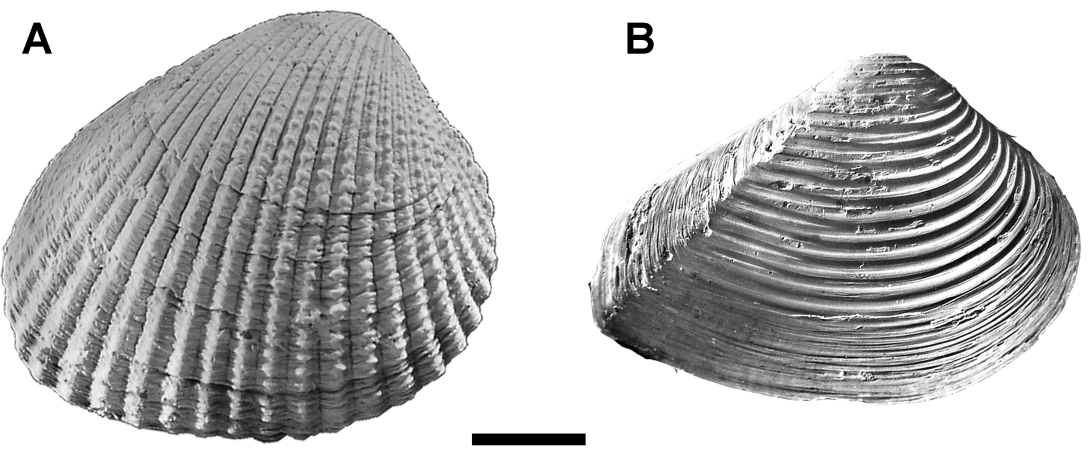

Figure 1 Case-studies of this work. (A) MACN-Pi 5197, C. paleopatagonica (Ihering, 1903) (Puesto Ramírez, Salamanca Formation, Early Danian) in lateral view. (B) MACN-Pi 3576, C. kokeni Ihering, 1899 (mouth of Santa Cruz River, Monte León Formation, Early Miocene) in lateral view. Scale bar $=10 \mathrm{~mm}$. Photo credit: the authors.

Full-size DOI: 10.7717/peerj.5051/fig-1

C. kokeni is the most abundant crassatellid from the Cenozoic of Patagonia (Argentina), being represented in the San Julián, Monte León, Camarones and Puerto Madryn formations (late Oligocene-late Miocene, Chubut and Santa Cruz provinces). The systematics of this species was reviewed by Santelli \& Del Río (2014), who regarded Crassatellites patagonicus (Ihering, 1907) as a junior synonymous of C. kokeni. For our analyses, 32 well-preserved shells of $C$. kokeni were used (including those previously assigned to C. patagonicus). These specimens come from Cañadón de los Artilleros, Punta Casamayor, Cabo Tres Puntas (late Oligocene-early Miocene, San Julián Formation, Santa Cruz Province); mouth of Santa Cruz River, Estancia Los Manantiales, Cañadón de los Misioneros, Monte Entrada (early Miocene, Monte León Formation, Santa Cruz Province); Camarones (early Miocene, Camarones Formation, Chubut Province), and Lote 39 (late Miocene, Puerto Madryn Formation, Chubut Province) (MACN-Pi 325-327, 331-332, 3576, 3600, 3907, 4775, 5374-5376; CIRGEO-PI 1501-1502; and CPBA 9404).

\section{Elliptic Fourier analysis}

The Elliptic Fourier Analysis (Kuhl \& Giardina, 1982) method was chosen to analyse the outlines of our examples because it allows to work with the variation presents in valves shape. The methodology employed to obtain different outlines is derived from Crampton \& Maxwell (2000) criteria. Each valve was digitally photographed in an inclined position with their growth lines placed parallel to the surface (Fig. 2A). The outlines obtained in different angles, regarding to the surface,were limited by coarse growth lines across the entire shell (Fig. 2B). Strict chronological ages of each individual have not been established, but previous analyses have well found a strong correlation between ages (based on the use of stable isotopes) and growth lines (Jones, 1988; Brey \& Mackensen, 1997; Jones \& Gould, 1999; Lomovasky et al., 2002). As a result, growth lines are a good proxy for the chronological age of specimens, and size is an estimation for relative time. In C. paleopatagonica annual growth lines are noticeable but in $C$. kokeni they are not so evident, being perceptible only in part of specimens' shells. For this species, outlines were taken at intervals of $10 \mathrm{~mm}$ 


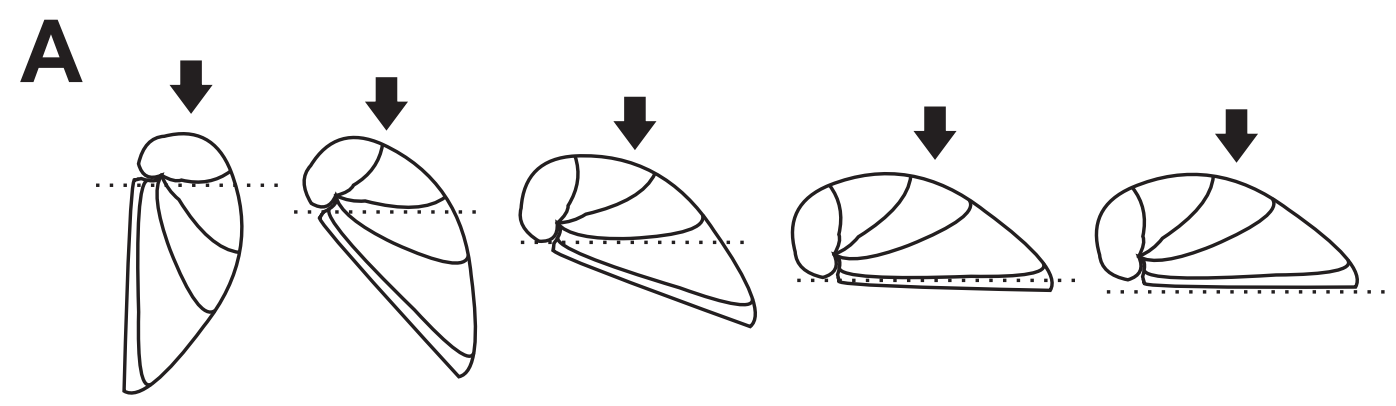

B

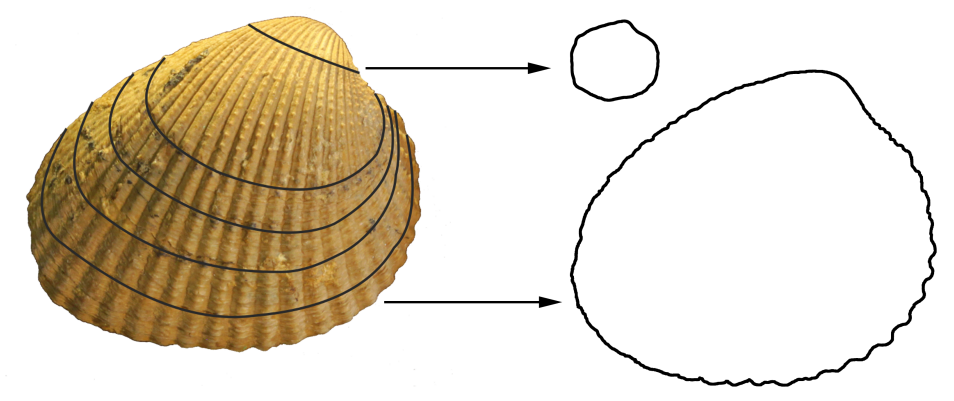

Figure 2 Applied methodology to obtain successive outlines of a single valve. (A) One valve oriented in different angles. Dotted lines indicate the parallel position of valves regarding to surface, arrows indicate position of digital camera. (B) Example of successive outlines captured in one specimen (MACN-Pi 5197). First and last outline illustrated. Photo credit: the authors.

Full-size DOI: 10.7717/peerj.5051/fig-2

along the axial length, following the procedure undertaken by Crampton \& Maxwell (2000) for Spissatella. This methodology allows to design an age-structured analysis for our data.

From a digitization procedure using a digital camera, 62 outlines were obtained from C. paleopatagonica, and 74 outlines from C. kokeni. Noise generated by external sculpture was removed from outlines with an image-edition software (Adobe Photoshop CS5) (following Crampton, 1995). Right valves were mirrored on the horizontal axis taking advantage of the equivalve character of shells, and the analysis was performed only with left valves. The outlines were grouped into three growth categories: "less than two", "two to four", and "more than four", each one indicating the number of precedent coarse growth lines. In the case of C. kokeni, due to different geographic and stratigraphic provenance of the studied specimens, four geological categories were established to group outlines: 'Monte León', 'Camarones', 'Puerto Madryn', and 'San Julián', each one representing the geological provenance of the material.

For each individual, chain codes were registered along the contour to calculate the Elliptic Fourier Descriptors (EFDs). Total Fourier power was calculated to estimate the optimal number of harmonics required for the analysis. The Fourier power of a harmonic is proportional to its amplitude and provides a measure of the amount of shape described by that harmonic (Crampton, 1995). A series of harmonics can be truncated when the value 


\begin{tabular}{llll} 
Table 1 & \multicolumn{2}{c}{ Univariate regression analysis between size (area) and shape (principal component). } \\
& Slope & Intercept & p-value \\
\hline C. paleopatagonica (PC1) & 763.09 & -387001.83 & $1.248 \mathrm{E}-15$ \\
C. kokeni (PC2) & 879.3 & -208871.5 & $8.149 \mathrm{E}-08$ \\
\hline
\end{tabular}

of average cumulative Fourier power reachs the $99 \%$ of the average total power (sum of the total harmonics used). The optimal number for this case was stablished in ten harmonics for C. paleopatagonica, and seven harmonics for C. kokeni. Outlines were normalized to discard effects of rotation, translation and size, using the parameters of the ellipse defined by the first harmonic (First Harmonic Ellipse method). Therefore, three of the four EFDs describing the first harmonic ellipse are constant for all the outlines (Crampton, 1995). The software Shape 1.3v (Iwata \& Ukai, 2002) was used for all the analysis.

\section{Morphospace construction and regression analysis}

A Principal Component Analysis (PCA) was performed from the variance-covariance matrix of normalized coefficients (Data S2 and Data S3 shows normalized Fourier coefficients for each outline and for each taxon, respectively). The shapes of the shell for mean and extreme morphologies (the latter are representations of specimens with score values corresponding to - two and +two standard deviations from the centre for each component) were reconstructed from the normalized coefficient mean values of the EFDs using the inverse Fourier transformations (Iwata \& Ukai, 2002) and plotted alongside the morphospace reconstruction. The growth and geological categories previously defined were both plotted on the PCA. Also, a Univariate Regression Analysis (URA) between sizes (obtained from the two-dimensional area of each outlines) and shapes using the principal components in both study-cases was conducted. The components were selected exploring the morphological variance obtained from PCA. The morphospace construction were performed using PAST 3.19 (Hammer, Harper \& Ryan, 2001), and the URA using R environment ( $R$ Core Development Team, 2017).

\section{RESULTS}

\section{C. paleopatagonica allometric growth}

The first three components of PCA explain $74.02 \%$ of the total variance (Fig. 3A). The first component (PC1) explains $46.55 \%$ of variance and represents the transition between subcuadrate (negative extreme) to subrectangular/subelliptic (positive extreme) outlines, with a posterior-ventral expansion. The second component (PC2; 20.16\% of variance) accounts for changes in convexity and width of umbones (more rounded umbos towards positive values and less rounded towards negative values). The third component (PC3; $7.3 \%$ of variance) captures variation in concavity of the lunular area (more concave lunule towards negative values and more convex lunule towards positive values). The URA between size and PC1 (selected because this component shows a transition between subcuadrate and subrectangular outlines) is significant ( $p$-value $<0.001)$ (Fig. 4A). Results of PCA and URA analyses are included in Table 1 and Data S4. 

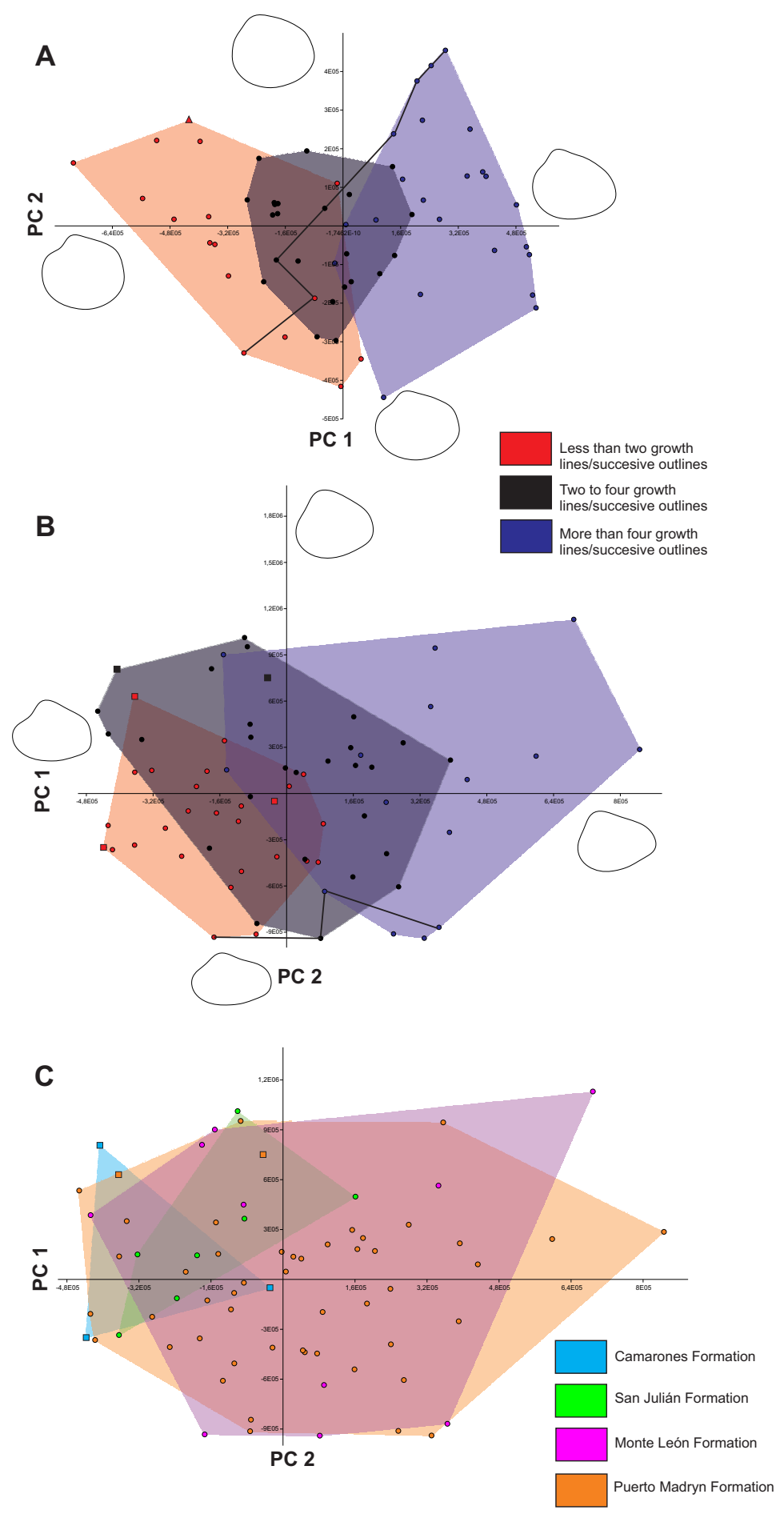

Figure 3 Results of principal component analyses. (A) C. paleopatagonica arranged by ontogenetic stage. (B) C. kokeni arranged by ontogenetic stage. (C) C. kokeni arranged by stratigraphic procedence. Color legends and the extreme morphologies of each principal component are illustrated in the graph. Black lines in A and B show ontogenetic trajectories of a selected specimen. Triangles indicate specimen previously assigned to Venericardia camachoi and squares indicate specimen previously assigned to C. patagonicus. 


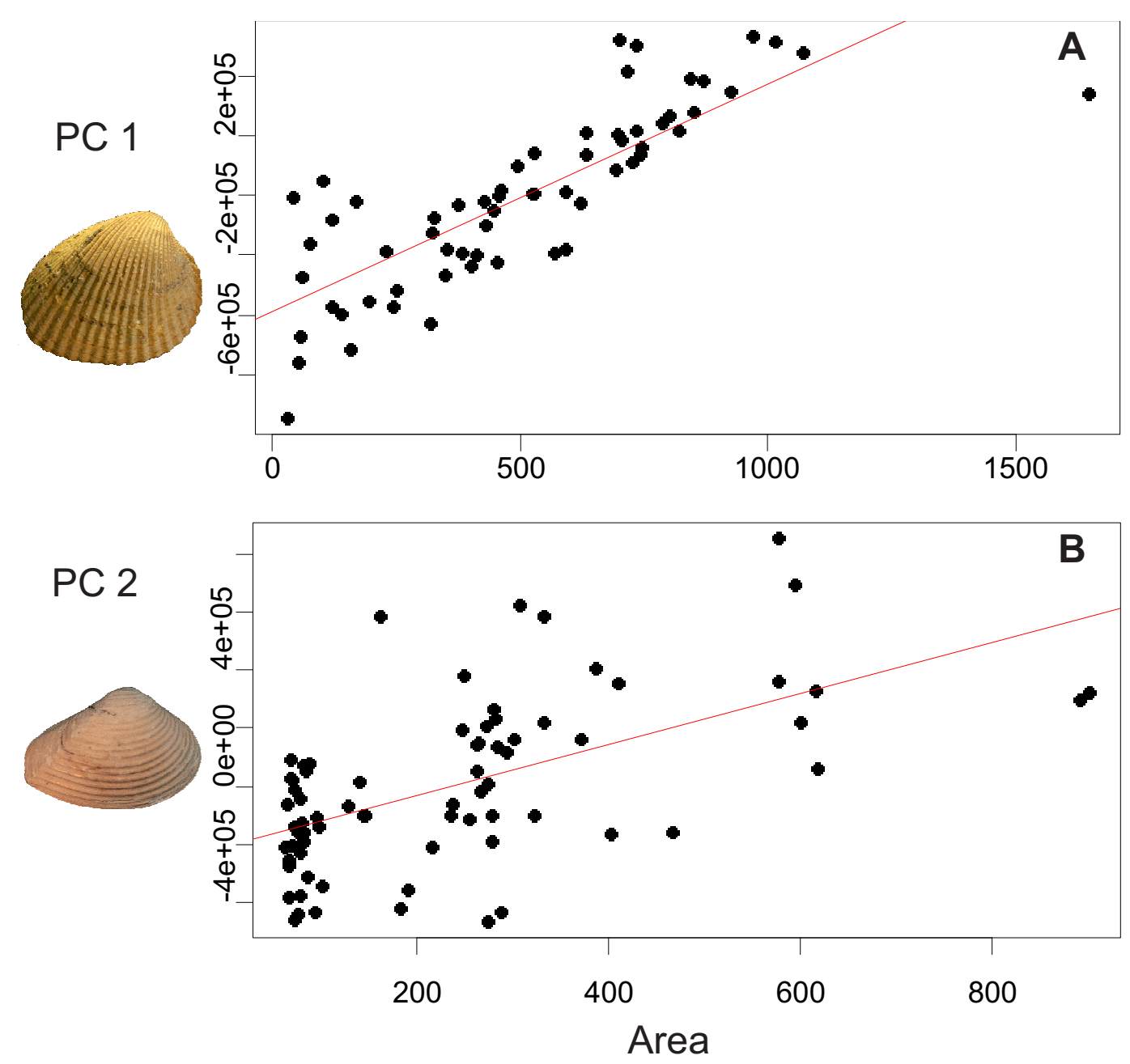

Figure 4 Results of univariate regression analyses, between area (size) and principal components (shapes). (A) includes first principal component obtained from C. paleopatagonica, and (B) includes second principal component obtained from C. kokeni. Red line indicates trend line. Photo credit: the authors. Full-size DOI: 10.7717/peerj.5051/fig-4

Growth categories plotted in the obtained morphospace show a transition across PC1 from juvenile to adult outlines. Variation across life-span in C. paleopatagonica can be distinguished in the successive outlines of each individual. Juvenile outlines are strongly rounded and shows subcentrally placed umbones. Towards more aged shells, an increase in the projection of posterior end is recognisable. Adult shells of this species have subrectangular to subelliptic outlines with anteriorly placed umbones. A reconstructed ontogenetic trajectory can be observed in Fig. 3A linking different stages of the same specimen in the morphospace (this ontogenetic trajectory was obtained from a single actual specimen, from which the largest number of outlines were acquired). Different allometric variation can be detected when overlapping extreme outlines of PC1. Posterior end has positive allometry, while the dorsal and anterior-ventral margins have negative allometry (Fig. 5A). 

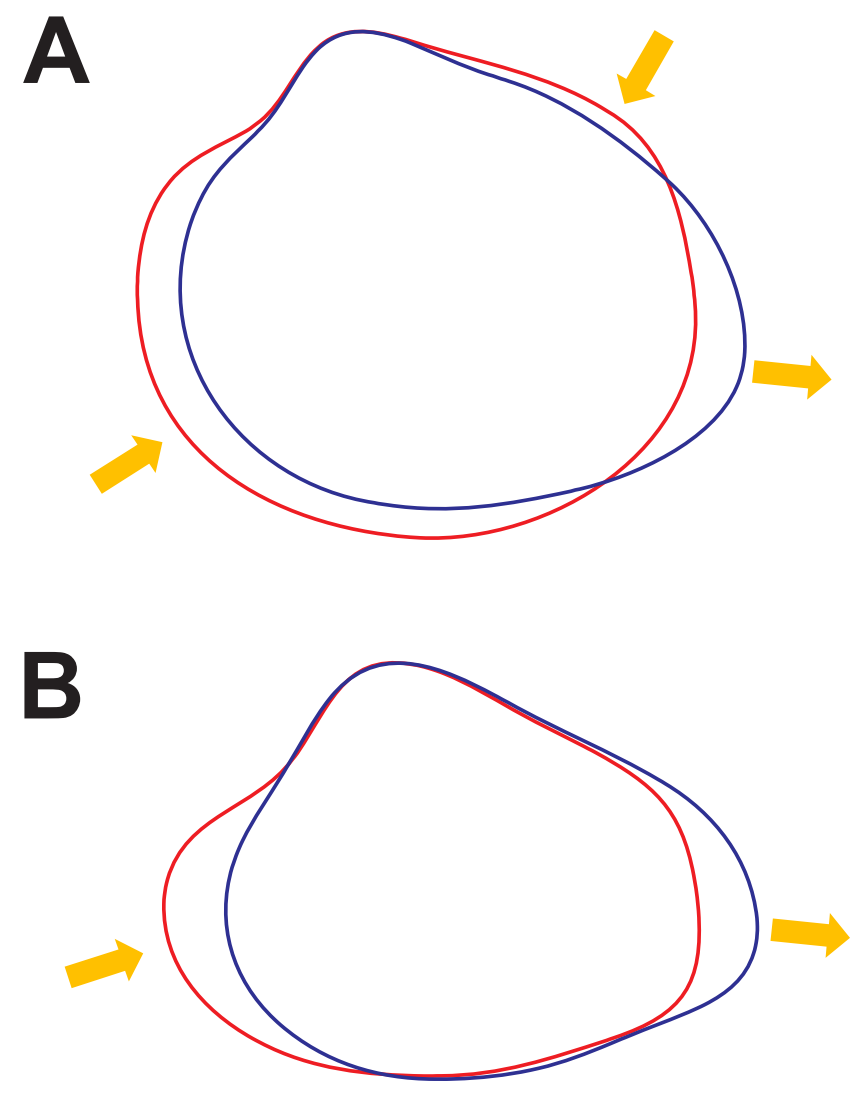

Figure 5 Overlapping of extreme outline configurations. (A) C. paleopatagonica. (B) C. kokeni. Red outline, juvenile specimens. Blue outline, adult specimens. Arrows indicate positive or negative allometry. Full-size DOI: 10.7717/peerj.5051/fig-5

\section{C. kokeni allometric growth}

In this case, the first three components of PCA explain $90.72 \%$ of the total variance (Fig. 3B). The first component (PC1; 66.66\% of variance) shows variation between outlines with subcentrally placed umbones and outlines with anteriorly placed umbones. The second component (PC2; 19.27\% of variance) reflects variation between more subtriangular and more subrectangular outlines. The third component (PC3; $4.79 \%$ of variance) is associated to variation between less and more truncated posterior end of valves. In this case, the PC2 was selected to the URA test, because this component explains the transition between less and more elongated outlines. The URA shows more scattered points on the graphs than C. paleopatagonica, which could be related to the different geological provenance of shells. Nevertheless, the result is significant ( $p$-value $<0.001$ ) (Fig. 4B). Results of PCA and URA analyses are included in Table 1 and Data S5.

Geological categories show a non-structured arrangement when they are plotted in the morphospace. The best sampled categories ('Monte León' and 'Puerto Madryn') occupy virtually the whole morphospace (Fig. 3C). Growth categories reflect a transition across the PC1 from juvenile to adult outlines. Juvenile outlines of $C$. kokeni are strongly subtriangular with pointed umbones, whereas adult outlines are markedly subrectangular having more 
rounded umbones. The reconstructed ontogenetic trajectory (Fig. 3B), obtained in the same way as the previous case, and the overlapping of both extreme outlines of PC2 shows an allometric variation similar to those observable in C. paleopatagonica (Fig. 5B). Specimens originally assigned to $C$. patagonicus by previous authors fall into the juvenile sector of the morphospace (Fig. 3B).

\section{DISCUSSION}

\section{Morphological change across life-span in C. paleopatagonica and C. kokeni and related species}

An allometric growth pattern shared by both species, C. paleopatagonica and C. kokeni was found in the analyses. Both taxa have positive allometry detected in the extension of posterior end, resulting in elongated adult shells. The study of ontogeny in bivalves had evidenced that some species show allometric growth in certain characters (Stanley, 1975; Stanley, 1977; Tashiro \& Matsuda, 1988; Savazzi \& Yao, 1992) and the morphological change recorded herein is also documented in other phylogenetically related infaunal bivalves. Subquadrate juvenile and elongated adult specimens of the carditid Claibornicardia alticostata (Conrad, 1833) have a similar allometric variation (Stenzel \& Krause, 1957, and D Perez, pers. obs., 2015 on syntypes ANSP 30562). Crampton \& Maxwell (2000) described a similar variation in some representatives of the crassatellid genus Spissatella, especially in the species S. subobesa (Marshall \& Murdoch, 1919) and S. poroleda (Finlay, 1926).

\section{Elongated adult morphology in other infaunal bivalves}

Ontogenetic trajectories have not been described in other infaunal bivalves. However, the same elongated adult morphology described here is known. Among archiheterodonts, the morphology documented for adult shells of C. paleopatagonica and C. kokeni can be observed in species of the genera Megacardita Sacco, 1899 (La Perna, Mandic \& Harzhauser, 2017); Neovenericor Rossi de García, Levy \& Franchi, 1980 (Pérez, Alvarez \& Santelli, 2017); Venericor Stewart, 1930 (Gardner \& Bowles, 1939); and Bathytormus Stewart, 1930 (Wingard, 1993; Santelli \& Del Río, 2014). Among other bivalve groups, this adult morphology is also recorded in species of the Veneroidea and Palaeoheterodonta. Some species of Veneridae genera as Anomalocardia Schumacher, 1817, Lirophora Conrad, 1863, Chionopsis Olsson, 1932, Lamelliconcha Dall, 1902, Macrocallista Meek, 1876, and Antigona Schumacher, 1817, among others, have adult shells with a projected posterior end and elongated outlines. Some Trigoniidae taxa lead this morphology to the extremes, with the development of wide and very projected posterior ends (e.g., Francis \& Hallam, 2003). As an example, Echevarría (2014) found a strong allometric growth developing in two phases in the trigoniid Myophorella garatei (Leanza, 1981) with a strong extension of the posterior margin.

\section{Taxonomic implications of allometric growth}

Differences between young and adult morphologies could have been be interpreted as taxonomic differences between species. In both studied cases, new species were proposed for specimens with young morphologies: Venericardia camachoi Vigilante, 1977 and 
C. patagonicus (Ihering, 1907). These taxa fall into the variation representing young specimens of C. paleopatagonica and C. kokeni, respectively. The case of C. kokeni and C. patagonicus was already mentioned by Santelli \& Del Rio (2014), being corroborated the synonymy in this study. Other examples are the carditids Neovenericor paranensis (Borchert, 1901) (late Miocene, Argentina), the adult morphology of which was described as Venericor crassicosta Borchert, 1901 (Pérez, Alvarez \& Santelli, 2017) and Neovenericor ponderosa (Suter, 1913) (late Oligocene, New Zealand), the young morphology of which was named Venericardia caelebs Marwick, 1929 (Beu \& Maxwell, 1990). These results reflect that this allometric change (included into the instraspecific variation) must be considered in taxonomic revisions of similar infaunal bivalves. These examples show that a different outline is frequently considered an important feature for taxonomic recognition but ontogenetic variation is not always taken into account (Alvarez \& Pérez, 2016).

\section{Ecological implications of the elongated adult morphology}

According to Stanley's experiments (1970), bivalve shells with streamlined outlines (cylindrical, blade-like, or disc-like) are the fastest burrowers. Elongated outlines could be related to fast burrowing in soft substrates but not in all cases. Also, Stanley (1970) established that moderately elongated burrowing species commonly use a large angle of rotation, having a strong forward component in their burrowing movement because of their eccentric axis of rotation. Elongated bivalves generally have a mode of life with the long axis in vertical position-for example, this is observed in living species of Anomalocardia-. Posterior portion of shell is directed to sediment surface, being achieved the elongated morphotype with a minimum of increase in shell growth, displacing the centre of gravity and the visceral mass of organisms to a deeper position (Stanley, 1970; Crampton \& Maxwell, 2000). Other possibly related effects could be increasing in stability against scour (Stanley, 1977; Stanley \& Yang, 1987; Francis \& Hallam, 2003) or reduction of exposure and predation (Crampton \& Maxwell, 2000; Francis \& Hallam, 2003). One possible way to reach this morphology could be to exploit the positive allometry of posterior end through the ontogeny.

Crampton \& Maxwell (2000) suggested that ontogenetic variation in Spissatella is an adaptation for life in more energetic environments with coarser substrates but these parameters were not explored in our data. Nevertheless, these conditions (along with others such as predation) may have played a part as selective pressures in the evolutionary history of these infaunal bivalves. Further stratigraphic structured analyses, including taphonomic and sedimentologic data, are needed to study these hypotheses.

\section{Evolutionary implications of allometric growth}

Ontogenetic changes in the mentioned infaunal bivalves seem to be similar and perhaps, could be induced by similar conditions. Allometry plays a significant role in evolutionary trends of most lineages (Gould, 1966b; Gould, 1977; Klingenberg, 1998). The study of allometric changes is sometines necessary for recognition of some cases of heterochronic processes (e.g., Shea, 1983; McKinney, 1984; Mitteroecker, Gunz \& Bookstein, 2005). Heterochrony is the change in relative time of appearance of characters already presents 
in ancestors (Gould, 1977; McNamara, 1986). Learning more about the ontogenetic trajectories and allometric changes present in different taxa is essential as the first step for heterochrony studies. These analyses require ontogenetic trajectories explored and phylogenetic relationships defined among species, being the cases like the ones described here fundamental and very important as a starting point.

\section{CONCLUSIONS}

Analyses of allometric growth allow to recognize similar ontogenetic changes in C. paleopatagonica (Ihering, 1903) and C. kokeni (Ihering, 1899). In both species the ontogeny is characterized by the presence of positive allometry in the growth of posterior end, resulting in elongated adult shells. The species Venericardia camachoi Vigilante, 1977 and C. patagonicus (Ihering, 1907), proposed as synonyms of both previously mentioned taxa, fall into the portion of the resulting morphospace that represents juvenile morphologies, so that the obtained results corroborate these synonymies.

This particular allometric growth, resulting in elongated adult shells, is presumed in other infaunal bivalve groups (e.g., Veneridae, Trigoniidae, Carditidae and Crassatellidae). The recognition of this character has taxonomic, ecologic and evolutionary implications, being important as the starting point for further heterochronic studies in bivalves. This study includes new observations and discussion about allometric growth in infaunal bivalves, and represented a contribution for thickening the literature of cases of allometric patterns.

\section{ACKNOWLEDGEMENTS}

The authors are in debt to curators M. Longobucco (MACN) and M. Tanuz (CPBA) who facilitated the access to collections. We thank to C. del Río (MACN) and F. Prevosti for their helpful comments in early stages of this work. We are in debt to the editor, K. De Baets (Friedrich-Alexander Universität Erlangen-Nürnberg), and the reviewers P. Milla Carmona (CPBA) and R. La Perna (Universitá di Bari), whose suggestions greatly improved this work. P. Milla Carmona suggested the lines at the end of introduction section.

\section{ADDITIONAL INFORMATION AND DECLARATIONS}

\section{Funding}

The authors were supported by CONICET (Argentina) through doctoral and post-doctoral grants. The funders had no role in study design, data collection and analysis, decision to publish, or preparation of the manuscript.

\section{Grant Disclosures}

The following grant information was disclosed by the authors: CONICET.

\section{Competing Interests}

The authors declare there are no competing interests. 


\section{Author Contributions}

- Damián Eduardo Perez and María Belén Santelli conceived and designed the experiments, performed the experiments, analyzed the data, contributed reagents/materials/analysis tools, prepared figures and/or tables, authored or reviewed drafts of the paper, approved the final draft.

\section{Data Availability}

The following information was supplied regarding data availability:

The raw data are provided in the Supplemental Files.

\section{Supplemental Information}

Supplemental information for this article can be found online at http://dx.doi.org/10.7717/ peerj.5051\#supplemental-information.

\section{REFERENCES}

Ackerly S. 1989. Kinematics of accretionary shell growth, with examples from brachiopods and molluscs. Paleobiology 15:147-164 DOI 10.1017/S0094837300009337.

Adams D, Rohlf FJ, Slice D. 2013. A field comes of age: geometric morphometrics in the 21st century. Hystrix 24:7-14.

Alvarez M, Pérez D. 2016. Gerontic intraspecific variation in the Antarctic bivalve Retrotapes antarcticus (Sharman and Newton, 1894). Ameghiniana 53:485-494 DOI 10.5710/AMGH.05.12.2015.2947.

Beu AG, Maxwell PA. 1990. Cenozoic Mollusca form New Zealand. Paleontological Bulletin of the New Zealand Geological Survey 58:1-518.

Borchert A. 1901. Die Molluskenfauna und das Alter der Parana-Stufe. Beiträge zur Geologie und Paläontologie von Südamerika. Neues Jahrbuch für Mineralogie, Geologie Palaeontoogie Beilagenband 14:171-245.

Brey T, Mackensen A. 1997. Stable isotopes prove shell growth bands in the Antarctic bivalve Laternula elliptica to be formed annually. Polor Biology 17:465-468 DOI 10.1007/s003000050143.

Brower J. 1988. Ontogeny and phylogeny in primitive calceocrinid crinoids. Journal of Paleontology 62:917-934 DOI 10.1017/S0022336000030183.

Brown C, Vavrek M. 2015. Small sample sizes in the study of ontogenetic allometry; implications for palaeobiology. PeerJ 3:e818 DOI 10.7717/peerj.818.

Christiansen P. 2012. The making of a monster: postnatal ontogenetic changes in craniomandibular shape in the sabercat Smilodon. PLOS ONE 7:e29699 DOI 10.1371/journal.pone.0029699.

Conrad TA. 1833. On some new fossils and recent shell of the United States. American Journal of Science and Arts 23:339-346.

Conrad TA. 1863. Descriptions of new recent and miocene shells. Proceedings of the Academy of Natural Sciences at Philadelphia 14:583-586.

Crampton JS. 1995. Elliplic Fourier shape analysis of fossil bivalves: some practical considerations. Lethaia 28:179-186 DOI 10.1111/j.1502-3931.1995.tb01611.x. 
Crampton J, Maxwell P. 2000. Size: all it's shaped up to be? Evolution of shape through the lifespan of the Cenozoic bivalve Spissatella (Crassatellidae). In: Harper E, Taylor J, Crame J, eds. The evolutionary biology of the Bivalvia. Geological Society London, Special Publications 177. London: Geological Society London, 399-423.

Dall WH. 1902. Synopsis of the family Veneridae and of the North American recent species. Proceedings of the United States National Museum 26:335-412 DOI 10.5479/si.00963801.26-1312.335.

De Baets K, Klug C, Monnet C. 2013. Intraspecific variability through ontogeny in early ammonoids. Paleobiology 39:75-94 DOI 10.1666/0094-8373-39.1.75.

Echevarría J. 2014. Ontogeny and autecology of an Early Cretaceous trigoniide bivalve from Neuquén Basin, Argentina. Acta Palaeontologica Polonica 59:407-420.

Ezcurra M, Butler R. 2015. Post-hatchling cranial ontogeny in the Early Triassic diapsid reptile Proterosuchus fergusi. Journal of Anatomy 226:387-402 DOI 10.1111/joa.12300.

Fink WL, Zelditch ML. 1995. Phylogenetic analysis of ontogenetic shape transformations: a reassessment of the piranha genus Pygocentrus (Teleostei). Systematic Biology 44:343-360 DOI 10.1093/sysbio/44.3.343.

Finlay HJ. 1926. New shells from New Zealand Tertiary beds: part 2. Transactions of the New Zeland Institute 56:227-258.

Francis AO, Hallam A. 2003. Ecology and evolution of Jurassic trigoniid bi-valves in Europe. Lethaia 36:287-304 DOI 10.1080/00241160310005115.

Gardner JA, Bowles E. 1939. The Venericardia planicosta group in the Gulf Province. United States Geological Survey, Professional Paper 189-F:143-215.

Gould SJ. 1966a. : Allometry in Pleistocene land snails from Bermuda: the influence of size upon shape. Journal of Paleontology 40:1131-1141.

Gould SJ. 1966b. Allometry and size in ontogeny and phylogeny. Biological Reviews 41:587-640 DOI 10.1111/j.1469-185X.1966.tb01624.x.

Gould SJ. 1977. Ontogeny and phylogeny. Cambridge: Belknap Press of Harvard University Press, 501.

Gould SJ. 1989. A developmental constraint in Cerion, with comments on the definition and interpretation of constraint in evolution. Evolution 43:516-539.

Hammer Ø, Harper DAT, Ryan PD. 2001. PAST. Paleontological statistics software package for education and data analysis. Palaeontologia Electronica 4:1-9.

Haug J, Waloszek D, Maas A, Liu Y, Haug C. 2011. Functional morphology, ontogeny and evolution of mantis shrimp-like predators in the Cambrian. Palaeontology 55:369-399 DOI 10.1111/j.1475-4983.2011.01124.x.

Horner J, Goodwin M. 2006. Major cranial changes during Triceratops ontogeny. Proceedings of the Royal Society B 273:2757-2761 DOI 10.1098/rspb.2006.3643.

Horner J, Goodwin M. 2009. Extreme cranial ontogeny in the upper Cretaceous dinosaur Pachycephalosaurus. PLOS ONE 4:e7626 DOI 10.1371/journal.pone.0007626.

Hughes N, Minelli A, Fusco G. 2006. The ontogeny of trilobite segmentation: a comparative approach. Paleobiology 32:602-627 DOI 10.1666/06017.1. 
Ihering H. von. 1899. Die Conchylien der Patagonischen Formation. Neues Jahrbuch für Mineralogie, Geologie und Palaeontologi 2:1-41.

Ihering H. von. 1903. Les Mollusques des Terrains Crétaciques Supérieurs del'Argentine Orientale. Anales del Museo Nacional de Buenos Aires terc. serie 2:193-229.

Ihering H. von. 1907. Les Mollusques fossiles du Tertiaire et du Cretacé Supérieur de l' Argentine. Anales del Museo Nacional de Buenos Aires, terc. serie 14:1-611.

Iwata H, Ukai Y. 2002. SHAPE: a computer program package for quantitative evaluation of biological shapes based on elliptical fourier descriptors. Journal of Heredity 93:384-385 DOI 10.1093/jhered/93.5.384.

Jones DS. 1988. Sclerochronology and the size versus age problem. In: McKinney ML, ed. Heterochrony in evolution: a multidisciplinary approach. New York: Plenum Press, 93-108.

Jones D, Gould SJ. 1999. Direct measurement or age in fossil Gryphaea: the solution to a classic problem in heterochrony. Paleobiology 25:58-187.

Klingenberg CP. 1996a. Multivariate allometry. In: Marcus LF, Corti M, Loy A, Naylor GJP, Slice DE, eds. Advances in morphometrics. New York: Plenum Press, 23-49.

Klingenberg CP. 1996b. Individual variation of ontogenies: a longitudinal study of growth and timing. Evolution 50:2412-2428

DOI 10.1111/j.1558-5646.1996.tb03628.x.

Klingenberg C. 1998. Heterochrony and allometry: the analysis of evolutionary change in ontogeny. Biological Reviews 73:79-123.

Korn D. 2012. Quantification of ontogenetic allometry in ammonoids. Evolution \& Development 14:501-514 DOI 10.1111/ede.12003.

Korn D. 2017. Goniatites sphaericus (Sowerby, 1814), the archetype of Palaeozoic ammonoids: a case of decreasing phenotypic variation through ontogeny. Paläontologische Zeitschrif 91:337-352.

Kuhl FP, Giardina CR. 1982. Elliptic Fourier features of a closed contour. Computer Graphics and Image Processing 18:236-258 DOI 10.1016/0146-664X(82)90034-X.

La Perna R, Mandic O, Harzhauser M. 2017. Systematics and Palaeobiogeography of Megacardita Sacco in the Neogene of Europe (Bivalvia, Carditidae). Papers in Palaeontology 3:111-150 DOI 10.1002/spp2.1072.

Leanza HA. 1981. Una nueva especie de Myophorella (Trigoniidae-Bivalvia) del Cretácico Inferior de Neuquén, Argentina. Ameghiniana 18:1-9.

Lestrel PE (ed.) 1997. Fourier descriptors and their applications in biology. Cambridge University Press, 484.

Lomovasky BJ, Brey T, Morriconi E, Calvo J. 2002. Growth and production of the venerid bivalve Eurhomalea exalbida in the Beagle Channel, Tierra del Fuego. Journal of Sea Research 48:209-216 DOI 10.1016/S1385-1101(02)00133-8.

Marshall P, Murdoch R. 1919. Some new fossil species of Mollusca. Transactions of the New Zealand Institute 51:253-258. 
Maunz M, German RZ. 1997. Ontogeny and limb bone scaling in two New World marsupials, Monodelphis domestica and Didelphis virginiana. Journal of Morphology 231:117-130 DOI 10.1002/(SICI)1097-4687(199702)231:2<117::AID-JMOR1>3.0.CO;2-B.

McKinney M. 1984. Allometry and heterochrony in an Eocene echinoid lineage: morphological change as a by-product of size selection. Paleobiology 10:407-419 DOI $10.1017 /$ S0094837300008423.

McNamara K. 1986. A guide to the nomenclature of heterochrony. Journal of Paleontology 60:4-13 DOI 10.1017/S0022336000021454.

Meek FB. 1876. A report on the invertebrate Cretaceous and Tertiary fossils of the upper Missouri country. In Hayden, FV (ed.): Report of the United States Geological Survey of the Territories. Invertebrate Paleontology 9:1-629.

Mitteroecker P, Gunz P, Bernhard M, Schaefer K, Bookstein FL. 2004. Comparison of cranial ontogenetic trajectories among great apes and humans. Journal of Human Evolution 46:679-698 DOI 10.1016/j.jhevol.2004.03.006.

Mitteroecker P, Gunz P, Bookstein FL. 2005. Heterochrony and geometric morphometrics: a comparison of cranial growth in Pan paniscus versus Pan troglodytes. Evolution \& Development 7:244-258 DOI 10.1111/j.1525-142X.2005.05027.x.

Monteiro LR, Beneditto AP, Guillermo LH, Rivera LA. 2005. Allometric changes and shape differentiation of sagitta otoliths in sciaenid fishes. Fisheries Research 74:288-299 DOI 10.1016/j.fishres.2005.03.002.

Olsson AA. 1932. Contribution to the Tertiary paleontology of northern Peru: Part 5, the Peruvian Miocene. Bulletins of American Paleontology 19:1-272.

Pannella G, Maclintock C. 1968. Biological and environmental rhythms reflected in molluscan shell growth. Journal of Paleontology 42(Supplement 2):64-80.

Pérez DE, Alvarez MJ, Santelli MB. 2017. Reassessment of Neovenericor Rossi de García, Levy \& Franchi, 1980 (Bivalvia: Carditidae) using a geometric morphometric approach, and revision of planicostate carditids from Argentina. Alcheringa 41:112-123 DOI 10.1080/03115518.2016.1196436.

Pérez DE, Del Río CJ. 2017. The family Carditidae (Bivalvia) in the early Danian of Patagonia (Argentina). Journal of Paleontology 91:1148-1165 DOI 10.1017/jpa.2017.69.

R Core Development Team. 2017. R: a language and environment for statistical computing. Vienna: R Foundation for Statistical Computing.

Rossi de García E, Levy R, Franchi MR. 1980. Neovenericor n. gen. (Bivalvia) su presencia en el Miembro Monte León (Formación Patagonia). Revista de la Asociación Geológica Argentina 35:59-71.

Rudwick MJS. 1968. Some analytic methods in the study of ontogeny in fossils with accretionary skeletons. Journal of Paleontology 42:35-49.

Sacco F. 1899. I Molluschi dei terreni terziarii del Piemonti e della Liguria. Part XXVII (Unionidae, Carditidae, Astartidae, Crassatellidae, Lasaeidae, Galeommidae, Cardiidae, Limnocardiidae e Chamidae). Turin: Carlo Clausen, 102. 
Santelli MB, Del Río CJ. 2014. Revisión de la subfamilia Crassatellinae (Bivalvia: Crassatellidae) del Paleógeno-Neógeno de Argentina. Ameghiniana 51:311-332 DOI 10.5710/AMGH.25.04.2014.2230.

Savazzi E, Yao P. 1992. Some morphological adaptations in freshwater bivalves. Lethaia 25:195-209 DOI 10.1111/j.1502-3931.1992.tb01384.x.

Schumacher CF. 1817. Essai d'un nouveau système des habitations des vers testacés. Copenghagen: Schultz, 288.

Shea B. 1983. Allometry and heterochrony in the African apes. American Journal of Physical Anthropology 62:275-289 DOI 10.1002/ajpa.1330620307.

Stanley SM. 1970. Relations of shell form to life habits in the Bivalvia (Mollusca). Geological Society Memoir 125:1-296 DOI 10.1130/MEM125-p1.

Stanley SM. 1975. Why clams have the shape they have: an experimental analysis of burrowing. Paleobiology 1:48-58 DOI 10.1017/S0094837300002189.

Stanley SM. 1977. Coadaptation in the Trigoniidae, a remarkable family of burrowing bivalves. Palaeontology 20:869-899.

Stanley SM, Yang X. 1987. Approximate evolutionary stasis for bivalve morphology over millions of years: a multivariate, multilineage study. Paleobiology 13:113-139.

Stenzel HB, Krause EK. 1957. In: Stenzel HB, Krause EK, Twining ST, eds. Pelecypoda from the type locality of the Stone City beds (Middle Eocene) of Texas. Texas University Publication 5704. Austin: Texas University, 1-237.

Stewart RB. 1930. Gabb's California Cretaceous and Tertiary type lamellibranchs. Special Publications of the Academy of Natural Sciences of Philadelphia 3:1-314.

Suter H. 1913. New species of Tertiary Mollusca. Transactions of the New Zealand Institute 45:294-297.

Tashiro M, Matsuda T. 1988. Mode of life in Cretaceous trigonoids. Fossils 45:9-21.

Tomašových A, Carlson Sandra J, Labarbera M. 2008. Ontogenetic nice shift in the brachiopod terebratalia transversia: relationship between the loss of rotation ability and allometric growth. Palaeontology 51:1471-1496

DOI 10.1111/j.1475-4983.2008.00809.x.

Urdy S, Goudemand N, Bucher H, Chirat R. 2010. Growth-dependent phenotypic variation of molluscan shells: Implications for allometric data interpretation. Journal of Experimental Zoology 314B:303-326 DOI 10.1002/jez.b.21338.

Wingard GL. 1993. A detailed taxonomy of Upper Cretaceous and Lower Tertiary Crassatellidae in the Eastern United States-an example of the nature of extinction at the boundary. In: United States Geological Survey Professional Paper \#1535. Reston: USGS.

Zelditch ML, Bookstein FL, Lundrigan BL. 1992. Ontogeny of integrated skull growth in the cotton rat Sigmodon fulviventer. Evolution 46:1164-1180

DOI 10.1111/j.1558-5646.1992.tb00626.x. 